\title{
Studies on intestinal absorption of amino acids and a dipeptide in a case of Hartnup disease
}

\author{
- \\ F. NAVAB AND A. M. ASATOOR \\ From Westminster Hospital Medical School, London
}

SUMM ARY A severely affected case of Hartnup disease is reported, where the patient responded rapidly to nicotinamide. This supports the view that all the clinical features, except reduced stature from general nutritional defect, are secondary to tryptophan and nicotinamide deficiency rather than to an unknown toxic factor. Severe malabsorption of both tryptophan and phenylalanine was demonstrated. The dipeptide carnosine was absorbed normally whereas when the two constituent amino acids, $\beta$-alanine and L-histidine, were ingested, absorption of the former was normal but that of the latter was grossly defective. The suggestion is advanced that in cases of Hartnup disease protein nutrition is maintained by intestinal uptake of amino acids as oligopeptides rather than as free amino acids. By contrast, both modes of absorption are probably important in normal subjects. Radiology of the small intestine is abnormal in Hartnup disease when a large amount of protein is admixed with the barium meal.

Hartnup disease is an autosomal recessive hereditary disease which manifests clinically with a pellagrous rash and neuropsychiatric abnormalities and is associated with a diagnostic type of aminoaciduria. Impaired transport of certain neutral amino acids has been demonstrated in the proximal renal tubules (Cusworth and Dent, 1960) and in the small intestine (Milne, Crawford, Girao, and Loughridge, 1960).

Since the first description of the condition (Baron, Dent, Harris, Hart, and Jepson, 1956) 43 cases have been reported (Jepson, 1966; Dauth, Dietel, and Ebert, 1966; Nielsen, Vedso, and Zimmermann-Nielsen, 1966; Wong and Pillai, 1966; Seakins and Ersser, 1967; Oyanagi, Takagi, Kitabatake, and Nakao, 1967; Pomeroy, Efron, Dayman, and Hoefnagel, 1968). This number is based on the view that eight cases in the family reported by Oyanagi et al (1967) were homozygous for the anomaly, although six of these were completely asymptomatic. This paper reports a further example of the disease and provides additional observations regarding the pathophysiology. Reviews of existing knowledge have been published by Jepson (1966) and by Milne (1969).

\section{Case Report}

An unmarried woman aged 25 was referred to the Psychiatric Department, Westminster Hospital, in an acute confusional state. She had always been a vegetarian and from the age of 7 had realized that she was abnormally photosensitive and was forced to avoid direct sunshine. When aged 12 she had an illness including 'fainting attacks', cramps, and diplopia. In the spring of 1966 she was able to sunbathe in the south of France without experiencing undue photosensitivity. At this time she was eating large quantities of fresh fruit and Camembert cheese, a diet of adequate tryptophan and nicotinamide content. In the spring of 1968 she visited relatives in Kenya, and had some difficulty in arranging an appropriate vegetarian diet. The main bulk of her diet at this time appears to have been maize, which is well known to be pellagrogenic owing to the low content of tryptophan and nicotinamide in this cereal.

A month after her return to England, a rash typical of pellagra developed in all areas of skin exposed to direct sunlight. She had a 'fainting' attack and became mentally confused. 


\begin{tabular}{|c|c|c|c|}
\hline & \multicolumn{3}{|c|}{ Free Urinary Amino Acids (mg/24 hr) } \\
\hline & $\begin{array}{l}\text { Present } \\
\text { Patient }\end{array}$ & $\begin{array}{l}\text { Another Case of } \\
\text { Hartnup Disease } \\
\text { (Evered, 1956) }\end{array}$ & $\begin{array}{l}\text { Normal Range for } \\
\text { Adults } \\
\text { (Soupart, 1959) }\end{array}$ \\
\hline Taurine & 85 & 23 & $22-185$ \\
\hline $\begin{array}{l}\text { Aspartic acid } \\
\text { Threonine }\end{array}$ & $\begin{array}{l}25 \\
\text { Poor }\end{array}$ & $617\}$ & $\begin{array}{l}1-22 \\
2-30\end{array}$ \\
\hline $\begin{array}{l}\text { Serine } \\
\text { Asparagine } \\
\text { Glutamine }\end{array}$ & $\begin{array}{l}\text { resolution, } \\
\text { not quan- } \\
\text { titated }\end{array}$ & $2290\}$ & $21-62$ \\
\hline $\begin{array}{l}\text { Glutamic acid } \\
\text { Citrulline }\end{array}$ & $\begin{array}{l}196 \\
20 \cdot 1\end{array}$ & $\begin{array}{r}332 \\
30\end{array}$ & $\begin{array}{l}<5 \\
<5\end{array}$ \\
\hline $\begin{array}{l}\text { Proline } \\
\text { Glycine } \\
\text { Alanine } \\
\text { Valine } \\
\text { Cystine } \\
\text { Methionine } \\
\text { Isoeleucine } \\
\text { Leucine } \\
\text { Tyrosine } \\
\text { Phenylalanine } \\
\text { Ornithine } \\
\text { Lysine } \\
\text { Histidine } \\
\text { 3-Methyl-histidine } \\
\text { Arginine }\end{array}$ & $\begin{array}{c}0 \\
680 \\
1080 \\
215 \\
28 \cdot 6 \\
47 \cdot 7 \\
293 \\
219 \\
490 \\
99 \\
21 \\
69 \\
865 \\
34 \\
3 \cdot 5\end{array}$ & $\begin{array}{r}5 \\
440 \\
825 \\
131 \\
39 \\
46 \\
151 \\
120 \\
630 \\
138 \\
-63 \\
770 \\
25 \\
-\end{array}$ & $\begin{array}{l}0 \\
71-116 \\
6-50 \\
0-26 \\
3-28 \\
2-8 \\
4-18 \\
1-15 \\
4-15 \\
4-25 \\
0-8 \\
0-12 \\
13-137 \\
18-52 \\
1-8\end{array}$ \\
\hline
\end{tabular}

Table I Comparative quantitation of urinary amino acids

\begin{tabular}{|c|c|c|c|}
\hline & \multicolumn{3}{|c|}{ Free Amino Acids in Fasting Serum $(\mathrm{mg} / 100 \mathrm{ml})$} \\
\hline & $\begin{array}{l}\text { Present } \\
\text { Patient }\end{array}$ & $\begin{array}{l}\text { Another Case of } \\
\text { Hartnup Disease } \\
\text { (Evered, 1956) }\end{array}$ & $\begin{array}{l}\text { Normal Range } \\
\text { (Brigham, Stein, } \\
\text { and Moore, 1960) }\end{array}$ \\
\hline Taurine & 1.49 & 0.82 & $0.41-0.82$ \\
\hline Aspartic acid & $0 \cdot 32$ & - & - \\
\hline Threonine & $\begin{array}{l}\text { Not } \\
\text { quan- }\end{array}$ & 0.61 & $1 \cdot 18-1 \cdot 72$ \\
\hline $\begin{array}{l}\text { Serine } \\
\text { Glutamic acid }\end{array}$ & $\begin{array}{l}\text { titated } \\
1.46\end{array}$ & $\begin{array}{l}5 \cdot 52^{1} \\
0 \cdot 72\end{array}$ & $\begin{array}{l}0 \cdot 69-1 \cdot 25 \\
0 \cdot 42-1 \cdot 15\end{array}$ \\
\hline Citrulline & 0.5 & - & - \\
\hline Proline & 1.8 & 1.29 & $1 \cdot 84-3 \cdot 34$ \\
\hline Glycine & $2 \cdot 1$ & 1.07 & $1 \cdot 12-1 \cdot 73$ \\
\hline Alanine & $2 \cdot 5$ & $2 \cdot 1$ & $2 \cdot 38-3 \cdot 73$ \\
\hline Valine & 1.5 & $1 \cdot 14$ & $2 \cdot 24-3.71$ \\
\hline Cystine & 0.20 & 0.60 & $0.71-0.97$ \\
\hline Methionine & 0.20 & 0.28 & $0.17-0.43$ \\
\hline Isoleucine & 0.47 & 0.48 & $0.69-1.28$ \\
\hline Leucine & $1 \cdot 21$ & 0.81 & $1 \cdot 42-2 \cdot 30$ \\
\hline Tyrosine & 0.61 & 0.66 & $0.81-1.45$ \\
\hline Phenylalanine & 0.43 & 0.71 & $0.69-0.95$ \\
\hline Ornithine & $1 \cdot 27$ & - & $0.62-0.76$ \\
\hline Lysine & $2 \cdot 3$ & 1.41 & $2.51-3.02$ \\
\hline Histidine & 0.73 & 0.43 & $0.79-1.48$ \\
\hline Arginine & 1.5 & - & $1 \cdot 22-1.93$ \\
\hline
\end{tabular}

Table II Comparative quantitation of amino acids in fasting serum

'Includes asparagine and glutamine.

In view of the severity of her symptoms she was urgently referred to hospital.

On examination she was found to be of reduced stature, the height being 149 centimetres. The exposed skin was thickened and indurated, and covered by a red, scaly rash with well defined margins. The skin around the mouth and eyes, and that of the lower part of the neck, was especially severely affected. The tongue was raw and swollen and indented by pressure from her teeth; in addition there was severe angular stomatitis, and profuse, uncontrollable salivation. She was confused, withdrawn and had no contact with reality. Her features were abnormal with a fixed continuous stare. At times she became hypomanic and made strange meaningless utterances in a loud and highpitched voice. There was incontinence both of urine and faeces. Neurological examination revealed a continuous flapping movement of the arms, and increased tone in the limbs with brisk tendon reflexes, but was otherwise normal.

\section{FAMILY HISTORY}

Her parents were not consanguinous. One brother had died at the age of 20 due to an accident. Her other brother, aged 28, and her maternal grandfather, although apparently healthy, were reputed to be unusually sensitive to sunlight. A paternal cousin has chronic schizophrenia. Urinary screening tests of her parents, brother, and paternal cousin revealed no abnormal aminoaciduria.

\section{INVESTIGATIONS}

The following investigations produced results within normal limits: haemoglobin, white cell count and differential count, erythrocyte sedimentation rate, serum folate and vitamin $B_{12}$, Schilling test, serum electrolytes, blood urea, lupus erythematosus cells in blood, Wassermann reaction and Kahn test, urinary and faecal porphyrins, faecal fat output, serum alkaline phosphatase, xylose absorption test, and peroral jejunal biopsy. Total serum proteins were normal but electrophoresis showed a low albumin content of $2.4 \mathrm{~g} / 100 \mathrm{ml}$ and a raised $\gamma$-globulin level of $2 \cdot 3 \mathrm{~g} / 100 \mathrm{ml}$. Although the fasting blood glucose was normal, a glucose tolerance test showed a mildly diabetic type of curve, the twohour specimen having a glucose content of $\frac{}{5}$ $139 \mathrm{mg} / 100 \mathrm{ml}$. There was no glycosuria throughout. Electroencephalography revealed a normal background activity, but in the posterior temporal $N$ region, frequent theta waves were found. Two weeks after therapy, when she was clinically normal ${ }_{N}$ the theta waves were still present but much less $\omega$ prominent, and there was now an asymmetry of the alpha activity, with a higher voltage in the right posterior temporal region than in the corresponding area on the left side. After three months of treatment, the abnormalities were still 0 present but to a lesser degree, whereas after $\stackrel{D}{\mathbb{D}}$ seven months the tracing was within normal $\frac{\Omega}{\mathrm{O}}$ limits.

\section{TREATMENT AND PROGRESS}

She was treated with intravenous nicotinamide, 300-500 mg daily, for three days. During the? following three weeks she was given $250 \mathrm{mg}$ nicotinamide daily, which was then reduced to a continuous maintenance dose of $150 \mathrm{mg}$ daily. 
Her abnormal mental state improved dramatically after 24 hours, and the rash subsided and disappeared after two weeks. She is now clinically normal, and is an intelligent, happy, and well adjusted young lady.

SPECIAL INVESTIGATIONS RELATED TO THE DIAGNOSIS AND ELUCIDATION OF THE PATHOPHYSIOLOGY OF HARTNUP DISEASE

Urinary amino acids were tested by paper chromatography using butanol, acetic acid, water and phenol, and ammonia (Smith, 1960) as developing solvents. The quantitative estimation of amino acids in a 24-hour urinary sample, fasting serum, and in the tolerance tests was carried out by ion-exchange chromatography on the Technicon amino acid analyzer, using the standard procedure (Technicon Handbook, 1956).

An aqueous suspension of L-tryptophan was ingested in the fasting state at a dosage of $0.07 \mathrm{~g} / \mathrm{kg}$ body weight. Urinary indoles were examined by two-dimensional paper chromatography in a basal 24-hour sample and in the urine collected for 24 hours after the amino acid (Dalgliesh, 1956; Jepson, 1966). Urinary indican was estimated in the sample by the method of Curzon and Walsh (1962).

L-phenylalanine in an aqueous solution at a dosage of $0.1 \mathrm{~g} / \mathrm{kg}$ body weight was given fasting, and serial serum samples were analysed for the amino acid. Similar tolerance tests were made using the dipeptide, carnosine ( $\beta$-alanylL-histidine) at a dosage of $0.286 \mathrm{mmole} / \mathrm{kg}$ body weight, and a mixture of the two free amino acids, $\beta$-alanine and L-histidine, at a dosage which would have been derived from the above dose of carnosine by hydrolysis (Asatoor, Bandoh, Lant, Milne, and Navab, 1970).

A modified barium meal radiograph was taken to demonstrate the effects of amino acid malabsorption. Two barium meals were carried out at an interval of five months; one unmodified using $300 \mathrm{ml}$ of Micropaque, and the other with the barium mixed with a paste of $25 \mathrm{~g}$ casilan.

\section{Results}

Paper chromatography of urinary amino acids was typical and diagnostic of Hartnup disease (Jepson, 1966) showing gross excess of many monocarboxylic monoamino acids with the notable exception of proline. The results of the quantitation of amino acids in urine and fasting serum are given in Tables I and II, and are compared with normal values and other published results in Hartnup disease.

The urinary indoles before tryptophan were within normal limits, both during the acute
PHENYLALANINE TOLERANCE TEST

$0 \cdot 1 \mathrm{~g}$. L-phenylalanine per $\mathrm{Kg}$. body weight.

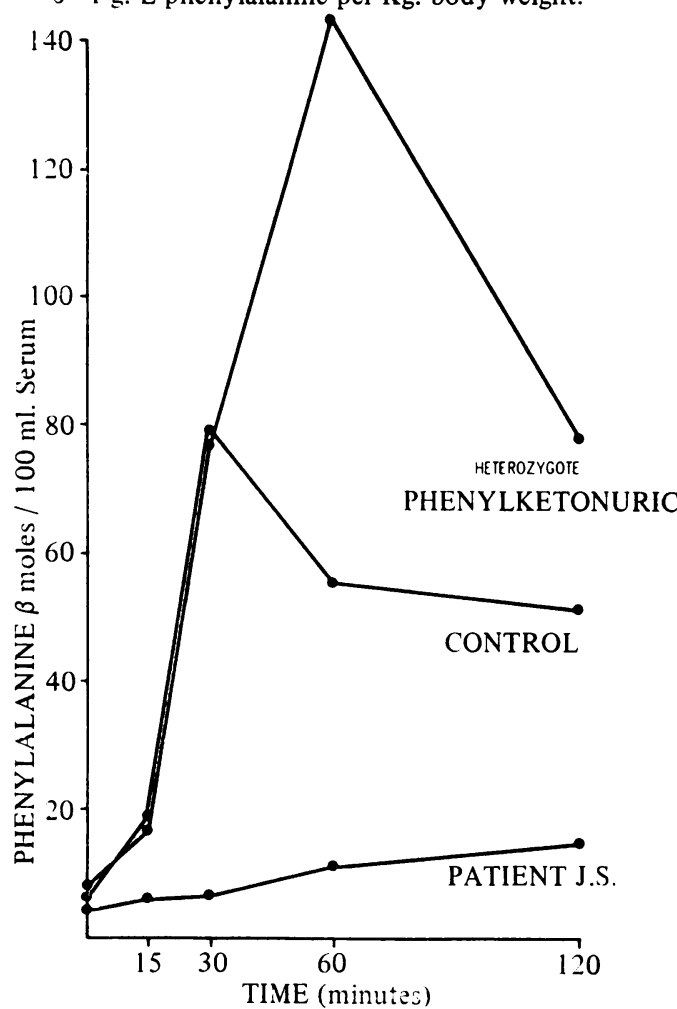

Fig. 1 Concentrations of serum phenylalanine after an oral load of the amino acid in the patient contrasted with that of two apparently normal controls. One of the normal patients shows absorption characteristics of a phenylketonuric het zrozygote.

stage of the illness and after treatment. After ingestion of the amino acid there was excretion of abnormally large amounts of indolyl-lactic acid, indolyl-acetic acid, and its glutamine conjugate, indolyl-acrylic acid, and also of indican. Indican excretion in the 24 hours after tryptophan was $1.34 \mathrm{~g}$, a grossly high level which suggests that at least $30 \%$ of the tryptophan is unabsorbed (Milne et al, 1960). By contrast kynurenine excretion was abnormally low, and was undetectable by paper chromatography both before and after tryptophan ingestion.

The results of L-phenylalanine tolerance compared with those of two apparently normal adults are given in Figure 1. It is seen that serum levels of phenylalanine in the patient are abnormally low, indicating malabsorption of the amino acid. The results in normals agree with those of Hsia, Knox, and Paine (1957), one of the subjects being a true normal, and the other within the range of heterozygote for phenylketonuria, an anomaly which occurs in about $1 \%$ of the general population and which is only detectable by this tolerance test.

The carnosine tolerance test was used to 

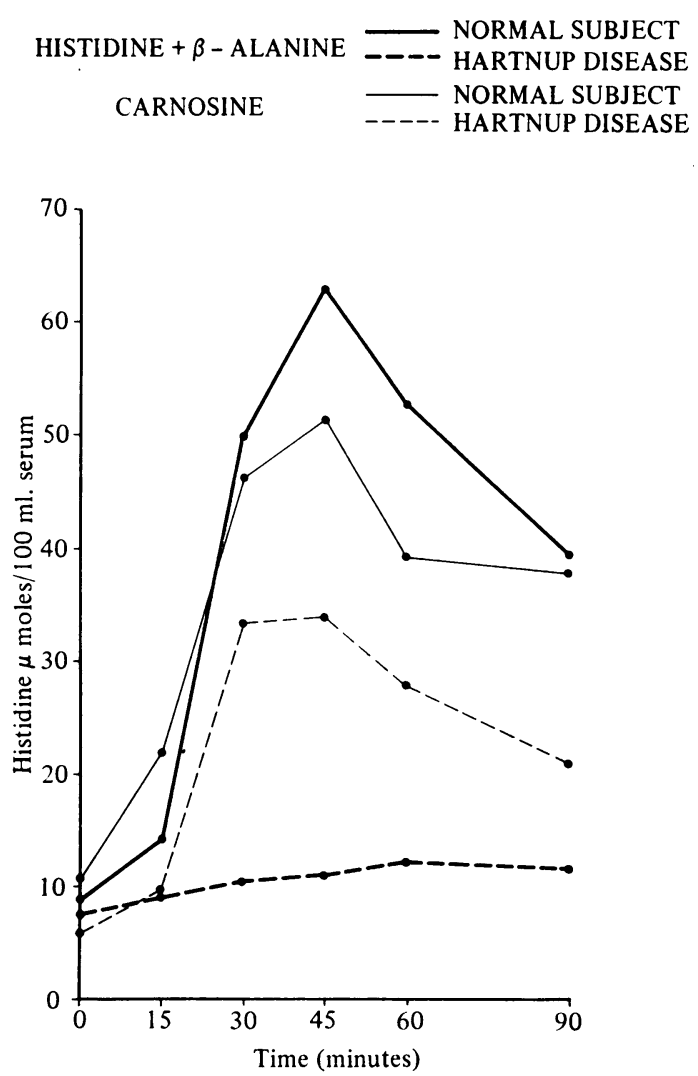

Fig. 2 Concentrations of serum histidine after oral carnosine and equivalent amounts of the free amino acids in a normal control and in the patient. The tolerance curve is abnormal after ingestion of free amino acids but within normal limits after carnosine.

investigate oligopeptide absorption in Hartnup disease. Carnosine was chosen because it was readily available in pure and bulk supply, and was known to be non-toxic and a common item of diet in non-vegetarians. Figures 2 and 3 compare serum histidine and $\beta$-alanine concentrations after ingestion of the dipeptide and corresponding amounts of the constituent free amino acids in the patient and in a representative normal subject. Absorption of both $\beta$-alanine and histidine is seen to be normal after the dipeptide, but the histidine absorption is abnormally low after ingestion of the amino acid mixture. Histidine transport in the small intestine would be expected to be abnormal in Hartnup disease, as it is excreted in the urine at high clearance (Evered, 1956) whereas $\beta$ alanine is a member of a separate amino acid transport group in the kidney (Scriver, Pueschel, and Davies, 1966) and intestine (de la Noüe, Newey, and Smyth, 1969), and would therefore be expected to be absorbed normally in Hartnup disease. The carnosine tolerance test is described more fully elsewhere (Asatoor et al, 1970), but comparison of the results in the patient and in

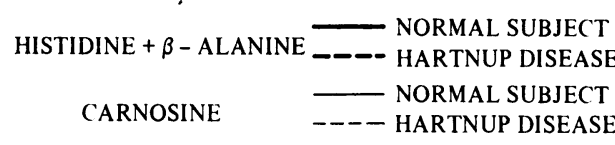

Fig. 3 Concentrations of serum $\beta$-alanine after oral carnosine and equivalent amounts of the free amino acids in a normal control and in the patient, showing normal absorption of this amino acid.

five normal subjects is given in Figure 4. Here the tolerance is expressed as the ratio of the 의 increments in serum concentration of the two $D$ amino acids. As they were given in equi-molecular amounts, the ratio of the increments (histidine/ $\mathrm{N}$ $\beta$-alanine) would be expected to be approxi- $\sigma$ mately unity provided that their respective rates $\tilde{O}$ of jejunal transfer were comparable. This ex- N pectation is seen to occur in the normal subjects $\sigma$ after both dipeptide and free amino acid in- $c$ gestion. In Hartnup disease the ratio is normal after carnosine, but is grossly low after the free amino acids. It can be concluded that $\beta$-alanine transport is normal in both tolerance tests, whilst that of histidine is normal after carnosine but greatly reduced after ingestion of $\propto$ free amino acid.

The technique of the modified barium meal has been used previously by Laws and Neale $\frac{0}{0}$ (1966) to demonstrate carbohydrate absorption in cases of intestinal disaccharidase deficiency, but has not been described to date in hereditary disorders of jejunal amino acid transport. The control barium meal and follow-through examination is normal (Fig. 5) but the one given after 


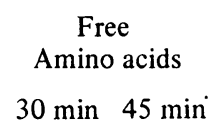

$30 \mathrm{~min} 45 \mathrm{~min}^{\circ}$

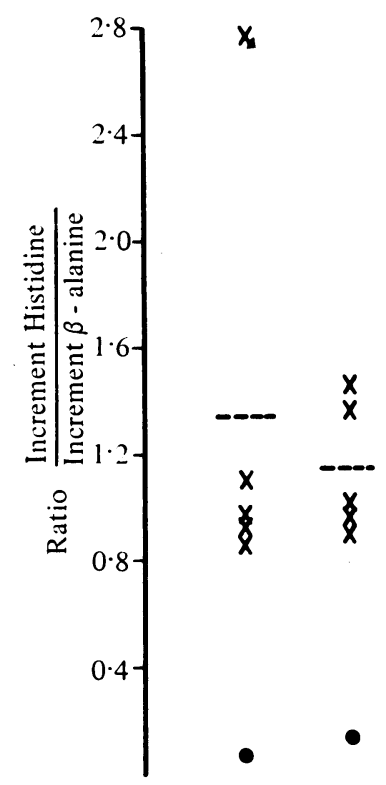

Fig. 4 Ratio of increments of serum histidine and of serum $\beta$-alanine after ingestion of carnosine and equivalent amounts of the free amino acids in the patient (closed circles) and five normal controls

(crosses). The results in Hartnup disease are normal after the dipeptide but abnormal after the free amino acids.

ingestion of the casilan meal shows abnormal results (Figure 6). There is considerable dilution of the contrast medium in the proximal jejunal segments with abnormal clumping of barium. Similar differences were not seen when the examination was performed in normal subjects.

\section{Discussion}

The clinical description of the present case of Hartnup disease resembles that of previous cases in most respects. Nevertheless, such reports are essential in rare diseases before an adequate statistical survey of the manifestations and clinical variations can be accurately assessed. The acute features of the disease occurred at a later age than in most cases, as a pellagrous rash has been found before the age of 10 years in $90 \%$ of the patients (Milne, 1969). In retrospect, however, in the present case early manifestations of the disease were almost certainly present at the age of 12. A combination of unusual photosensitivity, mild neurological disorder, and 'fainting attacks' is suggestive of Hartnup disease, and should be an indication for urinary

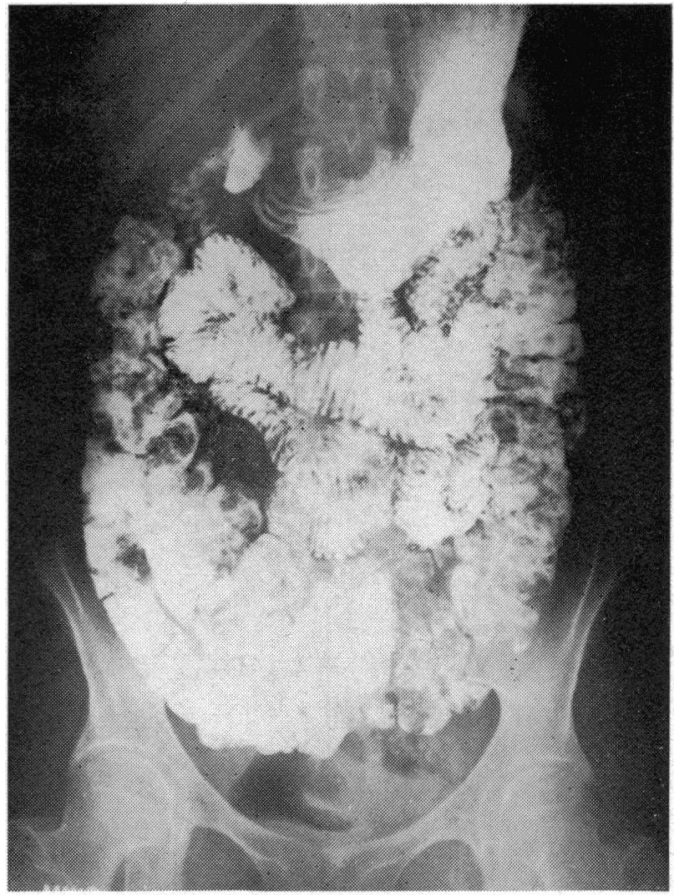

Fig. 5 Control barium meal showing normal small intestinal pattern.

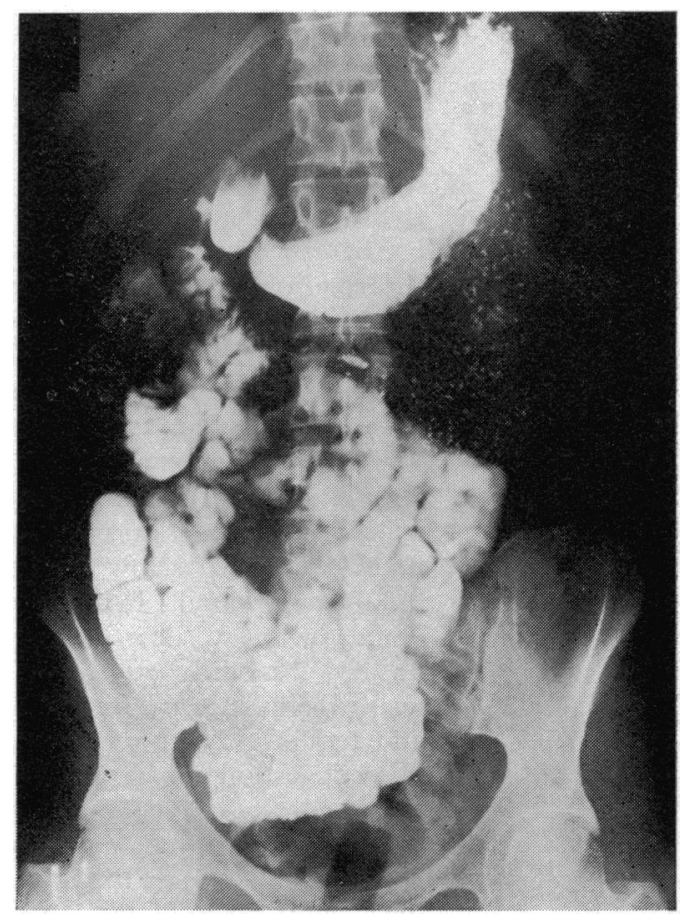

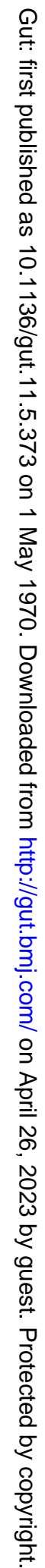

Fig. 6 Casilan barium meal shows dilution o, contrast in proximal jejunum with clumping. 


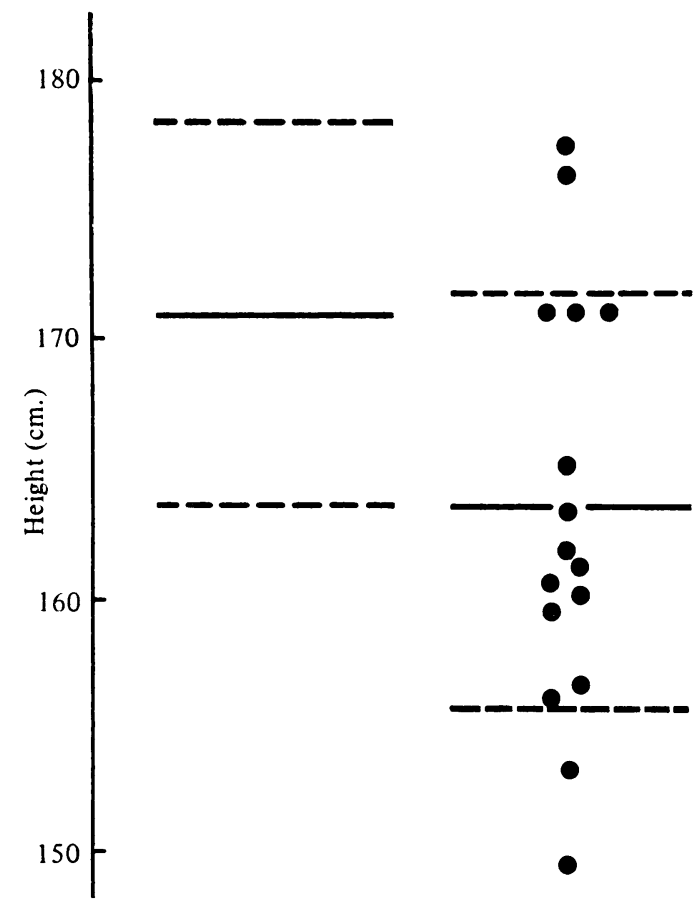

Fig. 7 Heights of reported cases of Hartnup disease compared with the mean (unbroken lines) and the standard deviation (broken lines) of the normal population. (Heights of female patients and of children have been corrected to that expected in the adult male.)

amino acid chromatography. In other affected families, presumptive heterozygotes have shown abnormal photosensitivity (Weyers and Bickel, 1958; Halvorsen and Halvorsen, 1963; Pomeroy et al, 1968). This has usually been explained as evidence of some nicotinamide deficiency despite a normal urinary amino acid chromatogram and lack of other clinical signs.

There has been previous controversy whether the neuropsychiatric manifestations are due directly to nicotinamide deficiency or whether they are produced by toxicity from products of bacterial degradation of unabsorbed amino acids in the colon. The rapid improvement after intravenous nicotinamide in the present case strongly supports the former alternative. The urine of the patient during the acute stage showed no evidence of possibly toxic metabolites such as indolyl compounds. In addition, both the present and previously described patients had little or no disability after amino acid tolerance tests, whereas normal subjects often feel nauseated and temporarily unwell, especially after tryptophan ingestion. Since absorption of the amino acid is slow and incomplete in Hartnup disease, the patients appear to be protected from any noxious effects. This interpretation also explains the acute exacerbation that occurred in the present patient after a diet predominantly consisting of maize which is low in tryptophan and nicotinamide. A similar exacerbation has previously been reported by Henderson (1958) in a case of Hartnup disease where the diet chosen consisted chiefly of corn flakes. In Hartnup disease there is reduced availability of tryptophan for nicotinamide synthesis, and consequently pellagrous features occur more rapidly and easily in cases of the disease than in normal subjects eating a similar, partially deficient, diet.

Furthermore, similar deficiencies of other essential amino acids, particularly threonine, phenylalanine, and the three branched chain amino acids, might well be expected but are not so clinically obvious. Colliss, Levi, and Milne (1963) claimed that patients with Hartnup disease were of reduced stature, the observed deficit of $5 \mathrm{~cm}$ being just significant statistically. Data from eight further patients with the disease are now available (Fig. 7) and the conclusion in these cases is much more certain, the probability value that the results are not due to chance alone being less than one per thousand. Cases of Hartnup disease are, therefore, at a slight nutritional disadvantage, but with the provision of a high-protein, western-type diet this is not severe, and excellent health can be expected if the patients take nicotinamide regularly.

The carnosine tolerance test may possibly explain one of the apparently anomalous features of the disease. Absorption from the jejunum of many essential amino acids is clearly grossly impaired. Thus the absorption of phenylalanine in the first two hours, estimated by the area under the tolerance curve (Fig. 1), is only 0.16 of the average normal value obtained from the results of Hsia et al (1957) using 19 normal subjects. Thus if a case of Hartnup disease depended on free amino acid absorption alone, the severity of the disorder would be incompatible with normal nutrition, and probably even with life. Despite evidence of grossly impaired intestinal absorption of phenylalanine and histidine, and increased loss via the renal tubules, plasma levels of these and other affected amino acids are lowered only slightly. As many of them are essential amino acids and must therefore be derived from exogenous sources absorption is likely to occur by another transport system not involving free amino acids.

The jejunal contents contain a complex mixture both of free amino acids and of numerous oligopeptides. The results of Newey and Smyth $(1960,1962)$ suggested that in addition to the transport of free amino acids, the small intestine might be able to take up dipeptides. The finding that oligopeptides of methionine and glycine disappear from the intestinal lumen more rapidly than the equivalent free amino acids (Craft, Geddes, Hyde, Wise, and Matthews, 1968; Matthews, Lis, Cheng, and Crompton, ? 1969) indicates that this may be an important mode of protein absorption. Following uptake, the peptides are hydrolysed either within the 
mucosal cells or at the cell surface (Newey and Smyth, 1962; Ugolev, 1965; Cheng, Navab, and Matthews, 1969) entering the blood as free amino acids. Carnosine was absorbed normally by this case of Hartnup disease, whereas after administration of the constituent free amino acids, transport of the histidine moiety was grossly deficient. If this oligopeptide is representative of the large number of similar compounds derived from protein hydrolysis, uptake of peptides may be the principal mode of absorption of essential amino acids in Hartnup disease. In normal subjects jejunal absorption is probably in the form of both free amino acids and oligopeptides, whereas in Hartnup disease uptake of oligopeptides may be the main transport pathway for those amino acids which cannot be taken up in the free form. This would account for the slight nutritional defect in Hartnup disease, shown clinically by pellagra and reduced stature, but which, with a full western-type diet, would still be adequate to ensure reasonably good nutrition. A period of undernutrition often antedates the clinical presentation (Jepson, 1966); possibly as a result of poor nutrition the small intestinal cell membrane peptidases are reduced (Solimano, Burgess, and Levin, 1967) and oligopeptide transport is impaired.

The results of the modified barium meal confirm the inadequate and slow absorption of products of protein digestion in Hartnup disease. As a diagnostic method, however, this technique will obviously be less useful than the disaccharide barium meal introduced by Laws and Neale (1966) for recognition of intestinal disaccharidase deficiencies. In any case suspected as Hartnup disease, the diagnosis can rapidly be confirmed or refuted by the simple and unequivocal method of urinary amino acid paper chromatography.

We thank Dr F. B. Gibberd for permission to publish this report of a patient who was admitted under his care, Dr P. Dally who referred the patient, and Professor M. D. Milne for his advice and help throughout the study.

We are grateful to Miss Margaret Tozer who assisted in the analyses.

\section{References}

Asatoor, A. M., Bandoh, J. K., Lant, A. F., Milne, M. D., and Navab, F. (1970). Intestinal absorption of carnosine and its constituent amino acids in man. Gut, 11, 250-254.

Baron, D. N., Dent, C. E., Harris, H., Hart, E. W., and Jepson, J. B. (1956). Hereditary pellagra-like skin rash with temporary cerebellar ataxia, constant renal aminoaciduria, and other bizarre biochemical features. Lancet, 2, 421-428.

Brigham, M. P., Stein, W. H., and Moore, S. (1960). The concentrations of cysteine and cystine in human blood and plasma. J. clin. Invest., 39, ii, 1633-1638.

Cheng, B., Navab, F., and Matthews, D. M. (1969). Site of intestinal dipeptide hydrolysis: Effect of L-amino acid oxidase. Clin. Sci., 37, 874. Site of hydrolysis of dipeptides during intestinal transport: an effect of Lamino acid oxidase. (In press.)
Colliss, J. E., Levi, A. J., and Milne, M. D. (1963). Stature and nutrition in cystinuria and Hartnup disease. Brit.med.J., 1, 590-592.

Craft, I. L., Geddes, D., Hyde, C. W., Wise, I. J., and Matthews, D. M. (1968). Absorption and malabsorption of glysine and glycine peptides in man. Gut, 9, 425-437.

Curzon, G., and Walsh, J. (1962). A method for the determina tion of urinary indoxyl sulphate (indican). Clin. chim. Acta, 7, 657-663.

Cusworth, D. C., and Dent, C. E. (1960). Renal clearances of amino acids in normal adults and in patients with aminoaciduria. Biochem. J., 74, 550-561.

Dalgliesh, C. E. (1956). Two-dimensional paper chromatography of urinary indoles and related substances. Biochem. J., 64, 481-485.

Dauth, K. H., Dietel, K., and Ebert, W. (1966). Das Hartnupsyndrom. $Z$. Kinderheilk., 95, 103-113.

De La Noüe, J., Newey, H., and Smyth, D. H. (1969). Transport of alanine isomers by rat small intestine in vitro. $J$. Physiol. (Lond.), 202, 100-101 P.

Evered, D. F. (1956). The excretion of amino acids by the human. A quantitative study with ion-exchange chromatography. Biochem. J., 62, 416-427.

Halvorsen, K., and Halvorsen, S. (1963). Hartnup disease. Pediatrics, 31, 29-38.

Henderson, W. (1958). A case of Hartnup disease. Arch. Dis. Childh., 33, 114-117.

Hsia, D. Y.-Y., Knox, W. E., and Paine, R. S. (1957). A case of phenylketonuria with borderline intelligence. Amer. J. Dis. Childh., 94, 33-39.

Jepson, J. B. (1966). Hartnup disease. In The Metabolic Basis of Inherited Disease, edited by J. B. Stanbury, J. B. Wyngaarden, and D. S. Fredrickson, 2nd ed., pp. 12831299. McGraw-Hill, New York.

Laws, J. W., and Neale, G. (1966). Radiological diagnosis of disaccharidase deficiency. Lancet, 2, 139-143.

Matthews, D. M., Lis, M. T., Cheng, B., and Crampton, R. F. (1969). Observations on the intestinal absorption of oligopeptides of methionine and glycine in the rat. Clin. Sci., 37, 751-764.

Milne, M. D., Crawford, M. A., Girao, C. B., and Loughridge, L. W. (1960). The metabolic disorder in Hartnup disease. Quart.J. Med., 29, 407-421.

Milne, M. D. (1969). Hartnup disease. Biochem. J., 111, 3-4.

Newey, H., and Smyth, D. H. (1960). Intracellular hydrolysis of dipeptides during intestinal absorption. J. Physiol. (Lond.), 152, 367-380.

Newey, H., and Smyth, D. H. (1962). Cellular mechanisms in intestinal transfer of amino acids. J. Physiol. (Lond.), 164, 527-551.

Nielsen, E. G., Vedso, S., and Zimmermann-Nielsen, C. (1966) Hartnup disease in three siblings. Dan. med. Bull., 13, 155-161.

Oyanagi, K., Takagi, M., Kitabatake, M., and Nakao, T. (1967). Hartnup disease. Tohoku J. exp. Med., 91, 383-395.

Pomeroy, J., Efron, M. L., Dayman, J., and Hoefnagel, D. (1968). Hartnup disorder in a New England family. New Engl. J. Med., 278, 1214-1216.

Scriver, C. R., Pueschel, S., and Davies, E. (1966). Hyper- $\beta$ alaninemia associated with $\beta$-aminoaciduria and $\alpha$ aminobutyricaciduria, somnolence and seizures. New Engl. J. Med., 274, 635-643.

Seakins, J. W. T., and Ersser, R. S. (1967). Effects of amino acid loads on a healthy infant with the biochemical features of Hartnup disease. Arch. Dis. Childh., 42 , 682-688.

Smith, I. (1960). Aminoacids, amines, and related compounds In Chromatographic and Electrophoretic Techniques, edited by I. Smith, Vol. I, pp. 82-142. Heinemann, London.

Solimano, G., Burgess, E. A., and Levin, B. (1967). Proteincalorie malnutrition: Effect of deficient diets on enzyme levels of jejunal mucosa of rats. Brit. J. Nutr., 21, 55-68.

Soupart, P. (1959). Urinary excretion of free amino acids in normal adult men and women. Clin. chim. Acta, 4, 265-271.

Technicon Handbook (1966). Techniques in Amino Acid Analysis, pp. 104-114. Technicon Instrument Co, Chertsey.

Ugolev, A. M. (1965). Membrane (contact) digestion. Physiol. Rev., 45, 555-595.

Weyers, H. and Bickel, H. (1958). Photodermatose mit Aminoacidurie, Indolaceturie und cerebralen Manifestationen (Hartnup-Syndrom). Klin. Wschr., 36, 893-897.

Wong, P. W. K., and Pillai, P. M. (1966). Clinical and biochemical observations in two cases of Hartnup disease. Arch. Dis. Childh., 41, 383-388. 